\title{
Las cooperativas de mujeres en España: ¿empoderamiento o perpetuación de roles de género?
}

\author{
Itzíar Gómez Carrasco ${ }^{1}$
}

Recibido: 31 de agosto de 2018 / Aceptado: 2 enero de 2019

Resumen. Este artículo presenta la experiencia de tres cooperativas dirigidas por mujeres en Andalucía (España) para ilustrar un contexto del sur de Europa donde el alto nivel desempleo y las políticas de austeridad han aumentado la importancia de las empresas sociales. Estas cooperativas se desarrollaron después de la crisis económica de 2008, en un contexto marcado por necesidades sociales emergentes, junto con recortes presupuestarios y cambios en las políticas sociales que afectaron particularmente a los países del sur de Europa. A las mujeres que fundaron estas cooperativas les atrajo un modelo empresarial que colocaba a las personas antes del capital para lograr objetivos sociales, junto con el objetivo económico de asegurar los medios de subsistencia de sus socias. Al discutir el concepto de empoderamiento de Kabeer, este artículo explora cómo, en el contexto andaluz, el modelo cooperativo permite a las mujeres mejorar sus condiciones de vida en general, creando empleos que se adaptan mejor a sus necesidades, mejorando su autoestima y fortaleciendo su sentido de empoderamiento, proporcionándoles a la vez las condiciones necesarias para una mayor flexibilidad y conciliación familiar. Sin embargo, dada la relativa ausencia de oportunidades alternativas, la búsqueda de flexibilidad de las mujeres y el predominio de su misión social por encima de fines lucrativos, también sugiere que el riesgo de perpetuar ciertos roles de género tradicionales permanece.

Palabras clave: Emprendimiento social; Desarrollo local; Cooperativismo; Conciliación familiar.

Claves Econlit: L26; L30; L31.

\section{[en] Women-led cooperatives in Spain: empowering or perpetuating gender roles?}

Abstract. This paper presents the experience of three women-led cooperatives in Andalusia (Spain)
to exemplify a southern European context where high unemployment and austerity measures have
increased the importance of social enterprises. These cooperatives developed in the aftermath of the
2008 economic crisis, in a context marked by emerging social needs, coupled with budgetary cuts and
changes in social policies that affected southern European countries in particular. The founders of
these women-led cooperatives came together attracted by an entrepreneurial model that placed people
before capital in the pursuit of social goals, coupled with the economic objective of securing the
livelihoods of its members. Discussing Kabeer's empowerment concept, the paper explores how in
the Andalusian context the cooperative model is enabling women to improve their overall living
conditions, by creating employment that is better suited to their needs, improving their self-esteem
and enhancing their sense of empowerment while providing the necessary conditions for greater

1 Universidad de Sevilla, España

Dirección de correo electrónico: igcarrasco@us.es 
flexibility and better work-life balance. Nevertheless, in a context marked by the relative absence of alternative opportunities, women's quest for flexibility and their focus on their social mission as opposed to profit-making, also suggests that the risk of perpetuating certain traditional gender roles remains.

Keywords: Social entrepreneurship; Local development; Cooperativism; Work-life balance.

Summary. 1. Introduction. 2. Women's empowerment, gender roles and cooperativism. 3. Sociopolitical environment for social enterprises in Andalusia. 4. Methodology. 5. The contribution of cooperatives to women's empowerment. 6. Empowerment or precarious employment?. 7. Conclusions. 8. References.

How to cite: Gómez Carrasco, I. (2019) Women-led cooperatives in Spain: empowering or perpetuating gender roles? REVESCO. Revista de Estudios Cooperativos, Segundo Cuatrimestre, $\mathrm{N}^{\circ}$ 131, pp. 48-64. DOI: 10.5209/REVE.63560.

\section{Introduction}

In Andalusia (one the largest and less advanced autonomous communities in Spain), social entrepreneurship (understood as the field where business and action for social change intersect) has been attracting growing attention since the 2008 crisis and has appealed to a wide range of people and business modalities. As in other parts of the world, the concept of social entrepreneurship is being used to refer to an increasingly diverse range of business initiatives that challenge traditional entrepreneurial models by placing people at the centre of their actions and superseding traditional business models that focused on economic gain (Kerlin, 2010; Martin and Osberg, 2007; Mair 2010).

The Andalusian context is marked by high unemployment and by a culture of extended working hours that renders family-life balance difficult and affects women in particular. The cooperative model seems to be responding to these issues by providing an enabling environment that allows women to improve their overall living conditions by offering a form of employment that is better suited to their needs. However, this response can be interpreted in different ways. On the one hand, the cooperative model can be seen as a solution that provides employment opportunities for women, improving their self-esteem and enhancing women's sense of empowerment while providing the necessary conditions for greater flexibility and a better work-life balance. On the other hand, employment in cooperatives is not always the result of real agency (understood as the power to choose), but can sometimes be considered a form of self-employment in contexts where job opportunities for women are largely absent. Furthermore, employment in cooperatives is sometimes precarious in nature, mainly as a result of low salaries, uncertain working conditions and limited institutional support.

This paper explores the cooperative model's potential to address work-life balance issues and provide more appropriate employment opportunities for women in a context marked by high unemployment. Cooperatives remain a traditional legal form but the experience of these three cooperatives suggests that the model (previously centred on the collective production and commercialisation of agricultural goods) is being re-invented by women to respond to the challenges of the context. The experiences of these women organisations deserve attention not 
only as illustrations of successful social enterprises but also as examples of how cooperatives are responding to a particular context and to the specific needs of women members.

This paper begins with a summary of the theoretical approach based on women's empowerment and gender roles in relation to cooperativism in Spain. The second section presents the socioeconomic context of Andalusia and the rationale for making this region the geographical focus of this research. The third part of the paper summarises the methodology and includes an account of the role I played as a researcher and in relation to the subject of this research. This is followed by a presentation of the findings and a discussion on whether the evidence suggests that cooperatives are empowering women members. The final section summarises the conclusions and suggests areas for future research.

\section{Women's empowerment, gender roles and cooperativism}

It can be argued that as a result of the context we live in and of the circumstances we have to deal with, "male and female are really two cultures and their life experiences are utterly different" (Millet, 1970: 31). The different gender roles that lie behind this statement can be defined as the particular socially constructed behaviours that are expected of men and women according to the social norms that apply in each context and setting. In the case of women, these roles are closely linked to women's status as primary carers, which "call for an expected role involving love, nurturing, self-sacrifice, homemaking and availability" (Lindsey, 2015: 2).

In different contexts across the world, it can be argued that "women of all ages, classes and ethnic groups are thoroughly conditioned and habituated to place others before themselves in thinking and acting" (Hall, 2013: 4). For example, Lindsey notes that "in acting out the roles of mother and employee, women are expected to be available at given times to satisfy the needs of family and workplace" (Lindsey, 2015: 3). Hence, what we observe in practice are situations where, in the absence of any real adaptation to women's "possible lives" in an evolving context, women's roles at home and in the workplace are in constant competition, often causing situations marked by tension, frustration and exhaustion. It is balancing these roles that constitutes a major challenge for most women. Furthermore, it is "women, dramatically more so than men, (who) are bound by family responsibilities" (Hall, 2013: 4).

The main focus of this research is to analyse how cooperatives contribute to improving the work-life balance of women members and to challenging gender roles by considering how their participation has affected their overall living conditions and their sense of empowerment. This analysis is based on women's shared experiences of growth, fulfilment and challenges faced in the three cooperatives offering a range of different products and services with a variety of social missions, including specialised psychological treatment for children, international consultancy services, childcare services and after-school activities for children and their families. 
In this article, we understand women's empowerment as "the processes by which those who have been denied the ability to make choices acquire this ability" (Kabeer, 2005: 13). According to Kabeer's conceptualisation of the term, empowerment has three closely associated dimensions. Firstly, agency (defined as the processes by which choices are made and put into effect); secondly, resources (the medium through which agency is exercised); and thirdly, achievements (the outcomes of agency). Understood in a positive sense, agency is the "ability/capacity to act on one's choice" versus a negative connotation in which empowerment is "power over: i.e. the capacity of certain actors to use violence or coercion to override the agency of others" (Kabeer, 2005: 15). Real agency goes beyond the notion of choice to also incorporate the idea of "challenging power relations" and self-perceptions (notably in terms of self-esteem and self-worth) (Kabeer, 2015). The resources available are in fact people's skills, abilities and capacities, which all form the medium through which agency is exercised. Thirdly, taken together, resources and agency lead to the third element of this empowerment model ("achievements"), which translate into different ways of realising our potential.

Following this definition, it can be argued that in order for this notion of choice to be real, the women involved must have had the capacity to have chosen differently as a result of the existence of real alternatives that confirmed the reality of this choice. Certain forms of behaviour that could be said to be based on real choice can sometimes be really based "on the denial of choice" (Kabeer, 2005). Indeed, some members of the analysed cooperatives described how their entrepreneurial project was motivated by the need to generate income and seek a self-employment opportunity in a context marked by high unemployment. Therefore, in this paper we explore if the experiences analysed contributed to empowering women members and to what extent the cooperative model was instrumental for achieving this.

Despite the improvements witnessed over the last decades, the crisis had uneven effects for men and women in Andalusia and structural gender inequalities remain. Even if it can be argued that over the last twenty years, women have improved their access to education and employment (following similar trends to those witnessed elsewhere in Europe), the crisis has increased existing inequality between men and women's terms of employment, making women's working situation more precarious (Espinosa and Matus, 2017). As a result of the crisis, some Andalusian women also undertook a type of domestic work that was traditionally assigned to them and which lacked economic or social recognition, sometimes in parallel with formal jobs (Espinosa and Matus, 2017). The increase in female participation in the job market was a result of the fact that unemployment particularly affected sectors that were "heavily masculinised" (Gálvez Muñoz and Rodríguez-Modroño, 2016: 14). At the same time, the crisis also brought about a return to a situation where, in the absence of resources, social needs (such as care services for children and elderly people) were addressed "at the community and domestic level" that tended to be "informal and feminised" (Zurbano and De la Cal, 2015: 59).

In terms of their participation, it is important to highlight that women are highly active in cooperatives in Andalusia. Cooperatives are the modality that is most frequently chosen by women who participate in collective entrepreneurship 
initiatives, providing 17,440 direct jobs and approximately 25,000 indirect jobs (equivalent to almost $80 \%$ of the female jobs in the social economy sector) in 2015 (Sanjuan Jurado, 2015: 179). In 2015, almost 50\% of the women who were members of cooperatives participated directly in decision-making as advisors and $39 \%$ held executive positions mainly as presidents or administrators (Sanjuan Jurado, 2015: 179). This not only points to the high participation of women in cooperatives but also to how they are challenging traditional roles within these structures by holding positions of greater power and influence. As a result, cooperatives are increasingly considered a reference model in terms of equality between men and women versus other business models (AMECOOP, 2010).

Recent years have witnessed a greater presence of women in various federations and associations of social entrepreneurs such as FEMPES, AMECOOP, AMESAL and CERES, which constitute "essential instruments for the representation of women in decision-making environments and in dialogue with public and private entities" (FAECTA 2014: 26). These organisations have also allegedly helped women entrepreneurs face those "obstacles and limitations that work as a glass ceiling or sticky floor” (FAECTA 2014: 26).

\section{Socio-political environment for social enterprises in Andalusia}

Social entrepreneurship is shaped by the context it operates in (Sekliiuckiene and Kisielius, 2015) and is conditioned by a wide range of factors such as the level of economic development, cultural and social elements and the policies in place (Fayolle and Matlay, 2010). In the case of Andalusia, these factors are crucial since they help to explain the reasons why cooperatives are becoming the preferred organisational form of social entrepreneurship (Sanjuan Jurado, 2015).

The economic crisis of 2008 showed the limitations and unexpected frailty of what was deemed to be a robust welfare system across the European Union (Defourny, 2010). This had profound effects in Andalusia, where the introduction of so-called "austerity" measures significantly reduced the scope of existing support policies, causing a profound questioning of the principles of the welfare system at a time when the need for social services and safety nets was paradoxically on the rise. As in other European countries, the crisis opened up "new scenarios for participation and partnership between economic actors in a mixed governance framework where the social economy had increasing protagonism" (Zurbano and De la Cal, 2015: 59). Third sector actors and private individuals became increasingly involved in emerging social issues, seeking solutions and intervening to fill in the gaps left by the State, particularly in the realm of social service provision. These "crisis-oriented factors" also included other aspects such as changes in normative situations, technological progress or new partnership opportunities unexpectedly brought about by the crisis (Perrini, 2006: 16).

In a context marked by increasing unemployment, many individuals also resorted to self-employment across Spain, creating their own work opportunities (Valenzuela and Molina, 2013). The particularly dramatic increase in unemployment in Andalusia (from 14\% in December 2007 to 36,3\% in December 
2013) (INE, 2018) made the social dimension of businesses gain importance, since the economic situation brought to the forefront the need to find "different and more humane" ways of doing business (Haro, 2015: 97). Existing business models in Andalusia also evolved, as an increasing number of companies placed people at the centre and promoted new consumption trends that embraced social justice, ethics and solidarity principles as key entrepreneurial values. The number of cooperatives grew regionally also, with Andalusia registering $18 \%$ of the total national cooperatives created in 2016 (INE, 2018).

The Andalusian socio-political and economic context of the aftermath of the economic crisis has been marked by various factors of relevance to the theme of this research. First, it is important to note that unemployment figures in Andalusia tend to be among the highest in the country (23\% in 2017 compared to the national average of 16\%) (INE, 2017), making the cooperative's employment creation potential a matter of special interest. Secondly, Andalusia is also the region with the highest number of social enterprises in the country (6.928), amounting to 23.9\% of the national total (Cabrera Blanco, 2015: 161) and employing a total of 64,950 workers $(52,217$ in cooperatives) (IECA, 2015: 15). The service, industry, agriculture and construction sectors constitute 60\%, 20\%, $12 \%$ and $8 \%$ respectively, out of the total social enterprises that exist (Cabrera Blanco, 2015: 161). Social entrepreneurship can thus be considered a strategic segment of the regional economy in Andalusia that deserves attention. Thirdly, if we take women's participation in this sector, approximately half of the people working in social enterprises in Andalusia were women in 2015 (FAECTA, 2016). Our focus on cooperatives is motivated by the fact that in Andalusia, out of the different social entrepreneurship modalities, cooperatives constituted not only the most popular legal structure for social enterprises in the region but also the most favoured by women participating in collective entrepreneurship initiatives (Sanjuan Jurado, 2015: 179).

Legal frameworks are key for ensuring an "entrepreneurial environment" (Mair, 2010) that enables social enterprises to flourish. The State and government play a central role in understanding a country's social enterprise model (Kerlin, 2009), since institutions, rules and norms in society are determining factors for shaping the kind of entrepreneurship that emerges in a country as well as its economic development model (Rueschemeyer, 2009). In fact, social enterprises can be shaped (albeit indirectly) by government decisions and actions as a result of their connection to both civil society and the economy (Baumal, 1990).

Hence, considering the Andalusian legal, institutional and policy framework is key for understanding which factors have been conducive to the creation of women-led enterprises in the region and which obstacles are hindering their development. In 2011, Spain was the first EU country to introduce a specific law on the social economy (Niţulescu and Rimac, 2014). Laws 5/2011 and 31/2015 constitute two key legal pillars for social enterprises operating in the country and define social economy as the combination of economic and business activities carried out by private entities for general economic and/or social interest (Law 5/2011). According to this law, the social economy hinges upon three basic principles: a) the primacy of individuals over capital (reflected in democratic and participatory governance structures); b) the contribution of all the results of the 
activities to the social objective of the entity; c) the promotion of solidarity with a view to supporting society's commitment to local development, equal opportunities, the integration of people at risk of social exclusion, social cohesion, the generation of employment, life-work balance and sustainability; d) independence with respect to public authorities (CEPES, 2018).

In terms of addressing gender equality, two key laws should be considered in relation to the social economy. Firstly, national Law 3/2007 of March 22 for the effective equality of men and women at the national level and at the regional level, Law 12/2007 of November 26 for the promotion of gender equality in Andalusia. These laws introduce "a set of measures to address issues such as vertical segregation, work-life balance, incorporation into the labour market on equal terms" and "the effective implementation of real equality in the framework of the companies and their productive activity" in the business agenda (Sanjuan Jurado, 2015: 180).

At the regional level, a series of policies in support of social entrepreneurship initiatives have been implemented in recent years. One of the key institutions lending technical assistance and subsidies to entrepreneurial projects is Andalucía Emprende, a public foundation attached to the regional government's Economic Department. With an extensive network of 215 field offices known as Entrepreneurial Development Support Centres (CADE), Andalucía Emprende has supported the creation of over 100,000 enterprises in the region. Associate experts assist the identification of the project and the design of the initial business plan. They also help to conduct a feasibility study to evaluate the prospective success of the initiative. Once the project is ready to be launched, entrepreneurs receive legal support for setting-up, creating and registering the company according to the model that is best suited to each project. Private and public funding opportunities are also sought by the experts in order to try to obtain advantageous loans for the entrepreneurial projects.

In every province of Andalusia, there is a specific CADE that specialises in the social economy and promotes cooperatives in urban environments (including service cooperatives such as the three analysed in this study), particularly those composed of young people and women. Although there are no specific grants or specific training programs for women, there are clauses that favour women victims of gender violence. The economic support lent to cooperative members also varies: women receive a higher sum to cover their social security costs and they receive it until they reach the age of 35 as opposed to men, who only receive it until they turn 30. Taken together, these legal, policy and institutional measures were positively valued by the cooperative members interviewed for this article who considered these policies to constitute the foundations of "an enabling legal framework" that supported their projects.

In Andalusia, the popularity of cooperatives can be explained by the fact that they occupy a central role in the legal framework as one of the categories for entities operating within the social economy together with: a) labour companies; $b$ ) mutual insurance companies; c) special employment enterprises; d) labour integration social enterprises; e) fishermen's guilds; f) associations of disabled and socially excluded persons; g) foundations (Law 5/2011). Specific regional laws have further strengthened the presence of cooperatives across Andalusia and might 
have also increased their appeal for women in particular. For example, Law 14/2011, of December 23, of Andalusian Cooperative Societies, established a series of unique components that did not appear in the international principles established by other cooperative norms, such as "the promotion of stable, quality employment with special emphasis on work-family balance and gender equality as a cross-cutting issue" (García Jiménez, 2015: 49). This element is relevant since it contributes to setting the legal base on which to lay the grounds for transformative measures with the potential to improve women's living conditions. Another element to be highlighted is the capacity-building principle incorporated by this law, since every cooperative must create a compulsory fund for training on issues linked to cooperativism, the promotion of gender equality as well as special training activities for members with integration difficulties at the social or professional level (García Jiménez, 2015: 49). It is also worth noting that this law includes gender equality as one of the cooperative principles in article 4 and it also appears as a cross-cutting principle to be applied in cooperatives (Law 14/2011). The recent amendment to the law (officially published in July 2018) to decrease the minimum number of cooperative members from three to two responds to civil society demands to simplify and extend this model to a greater number of entrepreneurial projects as part of ongoing efforts to further promote cooperatives as an integral part of the social economy.

It can be argued that the legal mechanisms available in each context determine whether social enterprises choose a cooperative or an associative legal form (Defourny, 2010). As a result, many social enterprises across the world are still using traditional third sector legal forms (Defourny, 2010), such as associations and foundations in Spain or cooperatives in the Andalusian region, in the absence of more specific legal structures. Cooperatives are deeply embedded in Andalusian culture as a model of association that was born in the mid-19th century. The arrival of democracy in the 1970s brought about a substantial development of this model (Algora Jiménez, 2015: 141). In fact, cooperatives have become increasingly popular across Spain in the aftermath of the economic crisis after falling in numbers during the crisis years (from 14,825 at the peak of the crisis in 2008 to 11,938 in 2014) and subsequently experiencing an increase in the number of new year-on-year registrations since 2015 (11,956 in 2015; 12,038 in 2016; and 12,056 in 2017) (Annual Statistical database, INE, 2018).

In Andalusia, cooperatives fall into four categories (services, consumption, transportation and special) and operate according to seven key principles (Rivero López, 2015: 198). These principles are at the heart of the three cooperatives analysed in this study. In terms of their creation and development, the adhesion of members of the cooperative was an open and voluntary process in all cases. The management of the cooperatives was democratic and followed the "one person, one vote rule" in decision-making processes. All partners made equitable economic contributions to the cooperative and decided on the use of funds in a consensual manner. All cooperatives worked to preserve their autonomy and independence in their collaborations and agreements with other entities while at the same time working with other cooperatives. The issue of promoting sustainable development in the communities they operated in was also important for the cooperatives. 
Beyond these basic principles, federations and various umbrella organisations linked to the sector argue that cooperatives are developing "new social practices in different areas of society and are actively promoting social innovation and the democratization of the economy" (FAECTA, 2016: 58). They argue that this innovation is the result of linking values such as participation, equal opportunities, sustainability and social responsibility to their entrepreneurial activity and developing "new ideas that satisfy the needs of society" (FAECTA, 2016: 59). Our interviews reveal that this positive and optimistic interpretation of the work of cooperatives in relation to society and the communities they serve is very present in the work of women members.

\section{Methodology}

The data gathered for this article was obtained during 2017 and the first half of 2018 through a desk review of secondary data (including academic literature, institutional reports and internet data).This information was complemented with primary data, namely a range of interviews with members of the cooperatives as well as with some of the key institutions and services that played a role in their creation and development in the province of Seville (Andalusia). Semi-structured interviews were conducted with women representing different types of entrepreneurial experiences and diverse profiles (age, level of education, sector of activity, etc). We decided to use a non-probabilistic sampling method to work with a series of experiences and testimonies that could illustrate the variety of initiatives that existed in the field of social entrepreneurship in the Andalusian context (Henry, 1990). Field observation and participation in internal meetings and activities provided additional insights.

To select the people interviewed, a "snowball sampling" method was chosen (Goodman, 1961). In its most basic form, this type of sampling involves "identifying respondents who are then used to refer researchers to other respondents" (Atkinson and Finch, 2011). Thus, following this sampling method, from the first interview with a cooperative member I was acquainted with, a network of experiences was woven to cover a broad spectrum of 12 women-led social enterprises. The three experiences selected for this research shared two common characteristics: they were all work cooperatives (cooperativas de trabajo) and composed of women members only.

A "persuasive case study approach" was applied to this research (Siggelkow, 2007). Following this approach, the three selected cases were chosen because the experiences shared by the informants provided relevant insights on how women-led cooperatives were responding to the difficulties inherent in the Andalusian context and on whether or not they could be framed as "empowering" according to our model. Although the three case studies presented in this article did not constitute a statistically representative sample, it can be argued that some of the data inferred might be relevant to other social entrepreneurship initiatives across southern Europe. Furthermore, following Siggelkow (2007), it can also be argued that these experiences were useful for enriching the discussion because a) they could motivate interesting research questions (as suggested in the concluding section); b) 
they could inspire new ideas for individuals interested in creating social enterprises; c) they could illustrate the theoretical elements presented in this paper (namely in terms of whether and how cooperatives can serve as enabling structures for women's empowerment).

It is also important to discuss my own position as a researcher. As a woman with two children living in Andalusia, I personally turned to the cooperative model in the quest for a better work-life balance at a time marked by family difficulties. In 2015, I started to collaborate with a cooperative and inspired by this positive experience, I resorted to this same model to found a work cooperative with two other members in 2018. Hence, my own motivation matches what has driven informants to set up a cooperative. My experience is thus relevant to this research and even if I cannot claim to be a neutral observer, the fact that my own experience mirrors many of the findings reflected in this paper constitutes an important element of the research.

The three case studies were selected for this article on the basis of their relevance for exploring the issue of women's empowerment in social enterprises that have adopted the cooperative legal form as their operating structure. Two of the three cooperatives were based outside the Andalusian capital of Seville in two small towns within the province. The third was based in the capital city. Although the individual profiles of the women interviewed varied (in areas such as their past career and socio-economic background), they were all aged between 35-50, had attended university and in the majority of cases had children. The following experiences were considered (names anonymized): a) Coop Dev (international consultancy services); b) Coop Care (child care) and c) Coop Psy (psychological services).

Coop Dev worked on international development issues, providing consultancy services (mainly technical support, evaluation and training) to a wide variety of entities that ranged from international organisations and NGOs to local government bodies, academia and other civil society actors at the local and global levels. The three women members came together attracted by the idea of developing what was to be "a life project rather than an enterprise", a professional project that would allow them "the freedom to do things their way".

Coop Care provided child support and care services. Its social mission was to support families by providing a wide range of care and educational services with a holistic approach that incorporates several different elements, since beyond offering thematic workshops, school dinners and after-school activities, Coop Care provided other services tailored to the specific needs of each family and incorporates innovative elements such as nutritional monitoring of children attending the centre. It also included logistical support and transportation to and from school and to evening classes across the village. Coop Care was created in 2017 by three friends with previous experience in a range of different professional fields linked to children, education and commerce. They began their social activity operating through a non-profit association that organized outreach and training activities for children and young people in collaboration with different local institutions. Over time, they decided to turn this work into a shared professional project and to establish a cooperative, driven by the need to make a living in a way 
that would also allow them flexibility to respond to family obligations and personal circumstances.

Coop Psy supported children with special needs through the provision of psychological, therapeutic and educational services that included new methodologies in combination with leisure activities that involved horses and combined different activities in a natural setting where the children played and learned together as part of their therapy. The women met through a training course offered by the local government on therapies involving horses. After the course, they discovered the existence of a hippodrome that was hardly used near their town and decided to develop a project to gain the support of the local authorities. The project was approved and they decided to establish a cooperative, since this was the model that "best suited their philosophy of solidarity and collective effort".

\section{The contribution of cooperatives to women's empowerment}

This research explored the experiences of these three women-led cooperatives. Beyond existing differences, the three experiences suggest that the cooperative model constitutes an enabling structure for enhancing women's empowerment and improving their quality of life. In this section, we present different findings that support this argument.

Firstly, the experiences show the cooperative model's potential to support efforts to reconcile work and family life. Family was one of the limitations most frequently mentioned by the women interviewed as a potential "brake" on their entrepreneurial activity in general. However, they all defended the view that the cooperative set-up had brought about positive changes in terms of work-life balance with respect to previous work experiences, since it was more feasible to achieve a balance with a flat organisational structure based on mutual support and equal salaries. Several concrete examples were shared in this regard. In two of the cooperatives, members covered the maternity leave of another member and also assumed more work when one of the members fell ill. These adjustments were made out of solidarity, understanding that all members would support each other as required.

The flexibility that the cooperative set-up provided, translated into concrete advantages, such as having time-off as required or working a reduced number of hours when needed. The fact that the majority of the women interviewed had children meant that creative solutions were sought to accommodate family needs and the scope for making this possible within the cooperative was an aspect that the women particularly valued. The cooperatives opened new opportunities for worklife balance, although they were not exempt from tensions due to the "double burden" faced by many of these women. Also, the traditional barriers between the personal and the professional were often blurred as a result of the shared use of time and resources. For instance, several women described having to complete tasks associated with the cooperative at home during their leisure time. While acknowledging the potential dangers of this, the women interviewed considered this an advantage, since it guaranteed greater flexibility. 
Secondly, another way in which forming the cooperatives contributed to improving women's living conditions and empowering them was by allowing members to place "the social" at the centre of their projects. This dimension was key for the women interviewed and they expressed pride in how they had succeeded in making their social values and mission central elements of their work. As one of the women noted, "social entrepreneurship models are either coherent or not social".

It was their desire to "meet the needs of society" and "to address a social gap or problem" that guided the definition of their projects and they felt that the cooperative model was instrumental for achieving this. Feeling that their work contributed to society and helped other people was a key added value for all the women interviewed. For this reason, the social value of projects can be highlighted as a key factor. For some women, what pushed them to create the cooperative above all was the need to develop an activity that could simultaneously "give back something good to society" and allow them "to make ends meet" while achieving a better work-life balance. For instance, it was their own struggles while raising their children that inspired the women who created Coop Care to provide a different (more holistic) type of support.

Beyond recognising that their work had intrinsic social value, several women members of the cooperatives considered that their projects and activities also contributed to the goal of achieving greater social justice (Fayolle and Matlay, 2010). The importance for the cooperative members of placing people above economic benefit was observed in each of the experiences analysed. The aims of each initiative focused on people both at the team level and at the level of the people who were supported by the cooperative's services. Their achievements and results were measured based on their contribution to social changes. As one of the members interviewed noted, "we have a triple bottom line that includes the social".

Thirdly, all the women interviewed stressed that creating the cooperatives had also empowered them by providing new skills and knowledge. These would contribute to the third dimension of empowerment, namely to the resources available, which all form the medium through which agency is exercised (Kabeer, 2005: 15). Real agency goes beyond the notion of choice to also incorporate the idea of "challenging power relations" and self-perceptions (notably in terms of self-esteem and self-worth) (Kabeer, 2015). As one of the women noted, "I never imagined I would learn so much in the process". The cooperatives allowed them to use their skills and capacities in a manner that had not always been possible in their previous jobs and this was also empowering for them. It strengthened their selfesteem and sense of achievement. The women used phrases such as "I never thought I would be able to do it", "discovering that I could overcome my vertigo was fantastic", which point to their sense of growing self-esteem and self-worth. This capacity-building dimension constituted another central factor worth highlighting, since women members of cooperatives recognised the importance of strengthening their capacities as one of the key factors that the members of cooperatives considered to be decisive for the success of their projects were their previous professional experience and acquired skills; and secondly, the balanced distribution of tasks among the members based on their different profiles, competencies and preferences. 
Fourthly, the co-responsibility in collective social entrepreneurship initiatives (risks, decisions, resources and shared capacities) was another positive factor considered empowering by the women entrepreneurs working in cooperatives. In the majority of cases, the entrepreneurial project was the result of an important and/or life-changing personal experience of a positive or negative nature (inspiration from travels, identification of a new need aligned with expertise) or brought about as a result of a negative experience (illness, divorce or loss of job/income). The notions of "solidarity" and "sisterhood" were also present in the three experiences.

Members resorted to constituting cooperatives as their preferred legal structure for the implementation of social entrepreneurship activities in the quest for a less hierarchical, more participatory and democratic legal set-up that would allow them to develop collective social entrepreneurship projects. As one of the members noted, 'we particularly value participation and equality in decision-making'. Feeling "more in control" was another key positive feature highlighted by the members, together with the sense of collective ownership they described ("we are building our own project, our own future") and strength ("together we are stronger").

An interesting factor to note was that all three cooperatives successfully built synergies through collaborations with various local initiatives (from town halls to third sector organizations and various federations of cooperatives). In this way, the cooperatives were effectively promoting cooperativism as "an alternative way of doing business" and were actively collaborating with other cooperatives that were sometimes led by women.

Finally, another empowering element was the fact that members believed that they were contributing to social innovation through their cooperatives by "doing things differently" and challenging traditional gender roles. The three experiences analysed reflected new ways of working and producing. The case of Coop Psy is particularly telling, since as one of the members noted, "many people were shocked to see women working in what was seen as a world of men".

\section{Empowerment or precarious employment?}

Women's access to employment can indeed improve their living conditions and their idea of "self-reliance", provided that the working conditions are fair and not precarious (Kabeer, 2005). These three women-led cooperatives emerged during the crisis or in its aftermath and their members were moved by the need to make a living in a manner that was compatible with their personal circumstances and preferences. Some of the women interviewed had lost their sources of income during the crisis (sometimes as a result of austerity measures that reduced the public funding that supported their work in the third sector) and hence, creating the cooperative was also a self-employment opportunity.

The women interviewed acknowledged the difficulties that were inherent to their respective activities (limited resources, uncertainty, long working hours, months without income). In fact, they all launched their cooperatives with limited financial resources and were faced with various degrees of financial insecurity at 
different stages in the development of their businesses. Some women also described having to overcome the feeling of "not being able to" before taking the step because of their low self-esteem and insecurities. Some of the women interviewed expressed a certain "vertigo" when using the word entrepreneurship, as if their activity did not fit in with their perception of achievements and success. This is linked to the fact that success often appears as a male characteristic that tends to be more an attribute of the male entrepreneur than of the female entrepreneur, who often has to "demonstrate more to get to the same place".

In fact, several of the women interviewed described processes of personal and professional growth that had been a direct result of their engagement in the cooperative. Some had strengthened their self-esteem and described feeling empowered as a result of their participation and involvement. They valued being in charge of their own project and considered their cooperative "a life project" and not "an economic project".

It was interesting to note that despite the difficulties, none of the women interviewed perceived their situation as precarious, despite modest salaries and the uncertainty of "how things will go in the future". The empowering elements described throughout this article certainly weighed more heavily than these limitations and compensated these difficulties. As one of the women noted, "the success of the collective project lies above any of our individual concerns" and for another member, the notion of collective ownership was much more important ("we are building our own project, our own future"). Furthermore, the feeling of solidarity was one of the most highly valued aspects of the work, since "our cooperative is a great nexus point for us all and we are like family".

Finally, one of the key factors that was fulfilling and empowering for the women was to feel that they were able to construct a professional project that was aligned with their social mission and social values. Many of the women had worked with associations and had acquired a "more social and alternative way of working with others" but it was the process of making their projects a feasible social enterprise that could "pay all the bills at the end of the month" that was particularly empowering for the members.

Following Kabeer's definition of empowerment, it can be argued that in order for this notion of choice to be real, the women involved must have had the capacity to have chosen differently as a result of the existence of real alternatives that confirmed the reality of this choice (Kabeer, 2005). In this regard, even if some members of these cooperatives described how their cooperative project was motivated by the need to generate income and seek a self-employment opportunity, the findings suggest that the cooperatives contributed to empowering women members and that the women chose cooperatives instead of other entrepreneurial models as a result of the advantages presented in this paper.

\section{Conclusions}

This paper has explored the question of how cooperatives can contribute to providing an enabling environment for women's empowerment and for challenging traditional gender roles. The experiences of these three women-led organisations 
suggest that cooperatives can be an effective tool for fighting discrimination both internally (through democratic functioning principles and inclusive organizational modes) and externally (through the focus of their activities and their social mission). They also tend to place members and beneficiaries firmly at the centre of their strategy while promoting dialogue for participatory and democratic decisionmaking processes in a way that is empowering and strengthens the self-esteem of women members.

These findings suggest that in the context of Andalusia, the cooperative structure is becoming more malleable and it is providing an enabling space for innovative projects that have found in the cooperative model the most adequate structure for their development. This re-interpretation is particularly interesting since, if we consider the case of the women participating in these three initiatives, it would seem that the cooperative model is allowing them to evolve and innovate within the structure of an existing (and traditional) legal form that is paradoxically better adapted to their needs than other legal forms of organisation/business models.

It can also be argued that cooperatives are also providing a model that can contribute to women's enhanced agency and empowerment (who is at the heart of each cooperative) by creating a space where traditional gender roles can be challenged and the quest for a better work-life balance occupies a central role. In principle, the three cooperatives analysed are linked to the "care economy" and sectors that are traditionally dominated by women. This trend has been noted in other places across the world, with social enterprises focusing on sectors linked to care activities (Nicolás \& Rubio, 2016; EU Parliament, 2015; Hechevarría et al., 2012).

Nonetheless, it can be argued that these cooperatives challenged traditional gender roles and the cooperative legal format offered certain advantages for women, allowing them to gain enhanced agency and empowerment and to improve their work-life balance; and secondly, providing an enabling structure with the potential to operate in certain fields of activity (such as care and consulting services) in innovative ways that challenged traditional female roles.

Following Kabeer, it is possible to contend that agency is transformative when gender roles are challenged, in ways that "do not simply address immediate inequalities but which are used to initiate longer-term processes of change in the structures of patriarchy" (Kabeer, 2005: 16). The structures that perpetuate gender inequalities must be challenged and collectively transformed (Rao et al., 2016) and in order to do this, it is important to identify the entry points that may allow transformative change to happen.

Agency is effective when employment opportunities are created with positive results (Kabeer, 2005) and in the case of these three cooperatives, it seems possible to argue that cooperatives have the potential to enable the transformative change required for advancements on gender equality. However, in order to better understand the contribution of cooperatives to these efforts, further research is required on this model as one that can potentially 'support women's empowerment and the self-perception of empowerment by the women-owners of the institution' (Datta \& Galey, 2012: 573). 


\section{References}

Algora Jiménez, J.M. (2015) El valor social e innovador de la Economía Social andaluza, IECA, Economía Social y Solidaria, pp. 141-145.

AMECOOP (2014) Monitoreo y buenas prácticas de liderazgos exitosos de mujeres, FAECTA.

AMECOOP, Diputación de Granada (2010) Diagnóstico sobre conocimiento e integración de políticas de igualdad y responsabilidad social empresarial de la provincia de Granada.

Baumol, W.J. (1990) Entrepreneurship: Productive, unproductive and destructive.

Cabrera Blanco, M. (2015) La medición de la economía social andaluza, IECA, Economía Social y Solidaria, pp. 156-167.

Defourny, J. (2010) Concepts and realities of social enterprise: a European perspective, pp. 57-87 i in A. Fayolle and H. Matlay, Handbook of Research on Social Entrepreneurship, Edward Elgar Publishing, Cheltenham, UK.

Espinosa Fajardo, J. y Matus López, M. (2017) El impacto de la crisis en las desigualdades de género en Andalucía: educación y trabajos. Un análisis para la acción, Oxfam Intermón.

FAECTA (2014) Monitoreo y buenas prácticas de liderazgos exitosos de mujeres.

Fayolle, A. and Matlay, H. (2010) Social entrepreneurship: a multicultural and multidimensional perspective, pp. 1-11 in A. Fayolle and H. Matlay, Handbook of Research on Social Entrepreneurship, Edward Elgar Publishing, Cheltenham, UK.

Gálvez Muñoz, L. and Rodríguez-Modroño, P. (2016) Una crítica desde la economía feminista a la salida austericida de la crisis, Atlánticas-Revista Internacional de Estudios Feministas, $\mathrm{N}^{\mathrm{o}}$ 1, pp. 8-33.

Hall, C.M. (2013) Women and Empowerment: strategies for increasing autonomy, Taylor and Francis.

Haro Pastor, G. (2015) Emprendimiento Social: Nuevas tendencias que están redefiniendo la economía, IECA, Economía Social y Solidaria, pp. 95-99.

Instituto Nacional de Estadística (INE) (2018) Base de datos anual estadística, INE (online).

Kabeer, N. (2005) Gender Equality and Women's Empowerment: a critical analysis of the third MDG, Gender and Development, № 1, Vol. 13, pp. 13-24.

Kerlin, J.A. (2009) Social Enterprise: A Global Comparison, Lebanon, NH: Tufts University Press.

Lindsey, L.L. (2015) Gender roles: a sociological perspective, Routledge.

Martínez Santaella, R. (2015) Autónomos de la Economía Social en Andalucía: de la invisibilidad al liderazgo en la recuperación económica, IECA, Economía Social y Solidaria, pp. 219-225.

Mair, J. (2010) Social Entrepreneurship: taking stock and looking ahead, pp. 15-27 in A. Fayolle and H. Matlay, Handbook of Research on Social Entrepreneurship, Edward Elgar Publishing, Cheltenham, UK.

Martin, R.L. \& Osberg, S. (2007) Social Entrepreneurship: the case for definition, Standford Social Innovation Review, Spring, pp. 29-39.

Millet, C. (2016) Sexual Politics, Columbia University Press.

Nichols, A. (2006) Social Entrepreneurship: new models of sustainable social change, Oxford University Press, UK.

Perrini, F. (2006) The New Social Entrepreneurship: What awaits Social Entrepreneurial Ventures?, Edward Edgar Publishing, UK, 2006. 
Rao, A., Sandler, J., Kelleher, D. \& Miller, C. (2016) Gender at Work: Theory and Practice for $21^{\text {st }}$ Century Organizations, Routledge.

Rivero López, A. (2015) Las cooperativas de trabajo asociado en Andalucía, IECA, Economía Social y Solidaria, pp. 197-201.

Sanjuan Jurado, L. (2015) Mujeres Cooperativistas, IECA, Economía Social y Solidaria, pp. 179-184.

Siggelkow, N. (2007) Persuasion with case studies, Academy of Management Journal, $\mathrm{N}^{\mathrm{o}}$ 50, Vol. 1, pp. 20-24.

Turner, S.G. \& Maschi, T.M. (2015) Feminist and empowerment theory and social work practice, Journal of Social Work Practice, No 2, Vol. 29, pp. 151-62.

Valenzuela García, H. \& Molina J.L. (2013) La emergencia de las "empresas de base humana" en España: ¿nuevo paradigma o consecuencia inevitable?, Documents d'Anàlisi Geográfica 2013, Vol. 59/3, pp. 523-542.

Zurbano, M. y de la Cal, M.L. (2015) La gobernanza de la economía social y solidaria para la inclusión social, IECA, Economía Social y Solidaria, pp. 58-64. 